\title{
Understanding media mentalities and logics: Institutional and journalistic practices, and the reporting of teachers' work
}

\author{
Aspa Baroutsis*
}

Griffith Institute for Educational Research, Griffith University, Brisbane

\begin{abstract}
This paper explores the 'media mentalities' about teachers and their work in the Australian print media. The notion of media mentalities draws on the theoretical concepts of discourse, mentalities, and mediatisation. This refers to the constructed realities and forms of thought in media coverage that circulate particular accounts. These are linked to institutional and journalistic practices in media that are governed by media logics. Drawing on newspaper text and interviews with journalists, the following practices are addressed: agendisation and accountabilisation which are both institutional practices; and the journalistic practices of factualisation, emphasisation, and sensationalisation - all of which operate globally, to some degree, across and within media institutions and media practitioners, and produce the news about teacher's work within the framework of these practices.
\end{abstract}

Keywords: media logic, media mentalities, teachers' work; newspaper construction of teachers, media discourse, frame analysis

\section{Introduction}

This paper theorises 'media mentalities' through understandings of discourse, mentalities, and mediatisation. Media mentalities are used as tools for developing an understanding of the practices of media organisations and journalists when communicating with society. These understandings enable educators to gain insights into 'media logics' of practice (Hepp, 2012), and are a way of referencing the 'general modus operandi of the media' (Asp, 2014). Specifically, media logics refer to the 'form of communication, and the process through which media transmit and communicate information' (Altheide, 2013). Perhaps more accurately, these mentalities are premised on the conceptual logic that institutional media frame content in specific ways, underwritten by a market or commercial logic (Asp, 2014; Landerer, 2013; Strömbäck \& Esser, 2014). Strömbäck and Esser (2014) suggest that the primacy of competition in market-derived practices shape the media selection of the issue and the way it is covered, that is, 'what' and 'how' news is covered. Stories are often selected for their 'attention-grabbing' value (Meyer, 2002); and storytelling techniques linked to media logics often focus on the 'dramatic narrative' that

\footnotetext{
*Email: a.baroutsis@griffith.edu.au
} 
incorporate controversy, conflict, dilemma, simplification, and sensationalism (Paletz \& Entman, 1981; Strömbäck \& Esser, 2014).

This paper theorises media mentalities, through the concepts of discourse, mentalities, and mediatisation. This is followed by an overview of the study and a detailed analysis of the five shared media practices. Shared media practices operate across and within media institutions and media practitioners. The five shared media practices, identified as agendisation, accountabilisation, factualisation, emphasisation, and sensationalisation, are then discussed, followed by some conclusions.

\section{Media mentalities}

The paper is framed using the theoretical concepts of discourse, mentalities, and mediatisation, which I have expressed collectively as 'media mentalities'. This collective term refers to the shared media practices that frame news coverage. These mentalities are constructed realities and forms of thought that circulate particular accounts, and are linked to institutional and journalistic practices in media. The first of these concepts is discourse. Discourses can determine the 'limits and forms of the sayable' (Foucault, 1991b, p. 59). In so doing, media can often define public 'knowledge' about teachers and schools. When questioning the conditions of the existence of discourse, Foucault (1972) expresses a curiosity for -

\footnotetext{
... that which rendered them possible - them and none other in their place; the conditions of their singular emergence; their correlation with other previous or simultaneous events, discursive or otherwise. (p. 59)
}

This includes 'prohibitions, exclusions, [and] limitations' associated with discourse, not in terms of an ultimate or absolute truth, but in relation to 'ways of speaking' about teachers and their work (Foucault, 1972, p. 193). Foucault (1981) adds, 'in every society the production of discourse is at once controlled, selected, organised and redistributed by a certain number of procedures' (p. 52). Media mentalities identify the selection practices that privilege certain framing of news events, perhaps seeking to influence public understandings of teachers and their work.

The second concept is that of 'mentalities' (Dean, 2010), drawn from Foucault (1991a) notion of governmentality. Dean suggests mentalities are 'forms of thought' that are usually 'not open to questioning', therefore, they are 'relatively taken for granted' by institutional practitioners (p. 25) while still remaining visible in society through public opinions (Campbell, 2004). These mentalities are 'representations' that shape the minds of populations and social agendas (Ricoeur, 2009). Mentalities or thoughts operate through a 'regime of practices' (Foucault, 1991c). Therefore, an analysis of mentalities 'is concerned with thought as it becomes linked to and is embedded in technical means for the shaping and reshaping of conduct and in practices and institutions' (Dean, 2010, p. 27). In the case of this paper, it relates to media institutions and the practices of journalism that operate as modes of influence within the production of knowledge (Foucault, 1991b).

The third conceptual tool relates to mediatisation that addresses the notion that mentalities are 'constructed' or 'mediated realities' (Couldry, 2003). Hjarvard (2009) identifies mediatisation as the "process whereby society to an increasing degree is submitted to, or becomes dependent on, the media and their logic' (p. 160). While acknowledging that this is not without complications (Hacking, 1999; Rawolle \& Lingard, 2010), Rawolle (2010) suggests 'mediatisation can be conceptualised as a set 
of identifiable practices' that can systematically impact the practices of individuals, groups, and systems (p. 22). While links could be made to Bourdieu's notion of the journalistic field and the capitals and habitus of the actors, this paper focuses on media logics. Altheide and Snow (1979) describe media logics as 'the process through which media present and transmit information' (p. 10). This can include 'how material is organized, the style in which it is presented, the focus or emphasis on particular characteristics of behavior, and the grammar of media communication' ( $p$. 10) as well as how is it 'treated, and given meaning [by institutions and practitioners] in order to promote a particular kind of presentation and understanding (p. 197). Consequently, the news process is not neutral (Mills \& Keddie, 2010).

This paper seeks to contextualise shared media practices in news production, as part of wider media logics that are likely to govern decision-making about media stories and their framing. These practices can therefore, at times, represent somewhat uncritical discursive representations of the perceptions in society, circulating public accounts of perceived 'truths' about teachers. These media constructs of teachers are likely to influence public perceptions of education systems and the teaching profession. Thomas (2006), in reviewing the work of a number of research studies about media coverage and popular opinion, found 'a significant relationship between media coverage and popular beliefs about schools, teachers and education" (p. 30). Additionally, she suggests that public discourse works to influence public opinion (Thomas, 2002). However, that is not to say that the media consumers do not have agency. Davis (1997) points out, 'people aren't dupes to the media ... and aren't mindlessly "swept along” by them' (p. 265). That is, the print media draw attention to certain ways of thinking about teachers, or as Lacey and Longman (1997) suggest, the press act as 'public educators'.

\section{Overview of the study}

The Australian media landscape presents an interesting case study. As Cunningham and Turner (2010) suggest, Australia's media sector is one of the most oligopolistic in the world with two proprietors accounting for 'more than 90 per cent of the daily metropolitan circulation' (Tiffen, 2010, p. 85). Rupert Murdoch is one of the two Murdoch's News Corp Australia dominates the industry with $57 \%$ of the daily newspaper circulation (Papandrea \& Tiffen, 2011). Additionally, Australian media coverage tends to adopt a more conservative political agenda (McKnight, 2010). This is a qualitative study focused on reportage about teachers in the print media. The analysis draws on qualitative data from three data sets: one gathered through a document study of newspaper texts from two national and eight metropolitan Australian newspapers and the second though semi-structured interviews. A third data set includes publicly available documents from the media organisations, owners, and chief editorial staff. The first data set, newspaper data, was drawn from a purposefully selected, non-consecutive timeframe of 18 months during 2009-2011, gathered using the Factiva database. The search term 'teacher' generated 1872 newspaper articles over the 18-month period. Of these, 149 articles were retained following a structured review process including a three-pass reading of the articles. Guided by a series of questions acting as inclusion criteria, only articles that made specific reference to teachers for the bulk of the article were retained. Thematic categories were developed after the reading process, refined, and then applied to the finalised articles. The second data set comprised of interviews with 19 participants: 17 teachers and two 
journalists (pseudonyms used). The participants were selected on the basis of a presumed 'fit' with the study and because they were identified as 'information-rich cases' by initially identifying two participants and then asking them if they knew of other people who should be interviewed (Patton, 2002). The same thematic categories identified in the news texts were applied to the interview data. In addition to the thematic analysis, I have also drawn on Entman's $(1993,2004)$ work on frame analysis in media studies. The combination of a frame and thematic analysis addresses the critique that frame analysis lacks operational precision (Matthes, 2009). Institutional practices are defined as those that relate to the broader media context while journalistic practices are those that are more specific to the media practitioners and the writing of the news story. The institutional practices of agendisation and accountabilisation and the journalistic practice of factualisation will be outlined in general terms using public documents and interview data from journalists and teachers. The other two journalistic practices, sensationalisation and emphasisation, will foreground discourses about teachers and their work predominantly using data from The Australian newspaper. By using this one newspaper as a case, I am not implying the homogeneity of news media types or sectors. However, when media are understood as an institution or as a system (Cook, 2005), different media organisations and news formats can be perceived as components of the whole media institution. Therefore, rather than being defined by their differences, what governs the various media organisations and formats can be conceptualised through the shared norm and practices (Strömbäck \& Dimitrova, 2011; also see Altheide \& Snow, 1979; Hjarvard, 2008).

\section{Practices of media logics}

The findings are structured around a number of media practices identified as media mentalities. These mentalities outline institutional and journalistic practices informed by media logics. I note here that, like Bourdieu (2011), I use the term 'journalist' in an abstract form and not in any way implying homogeneity within the profession. Instead, my focus is on journalistic practices, processes, and products which have a tendency have greater similarities across individual media corporations.

Agendisation and accountabilisation are institutional practices governed by media logics, while factualisation, emphasisation, and sensationalisation are journalistic practices derived from the institutional practices, but focusing on the writing of the news article. The institutional practices of agendisation and accountabilisation and the journalistic practice of factualisation will be outlined in general terms using interview data from journalists and teachers. The other two journalistic practices, sensationalisation and emphasisation, will foreground discourses about teachers' work predominantly using data from news texts.

\section{Agendisation and accountabilisation}

Every day, many newsworthy events about schooling occur, both locally and globally. However, given the magnitude of possible stories, the press reports on a fraction of these events. This raises questions about the mentalities that govern the selection and

filtering practices and processes that give certain events representational value in preference to others. Institutionally, this practice is known as 'gatekeeping', a 
'process of selecting, writing, editing, positioning, scheduling, repeating and otherwise massaging information to become news' (Shoemaker, Vos, \& Reese, 2009, p. 73). Through this practice of gatekeeping, journalists and editors can frame the news for their readers (Entman, 1993). Framing comprises the elements of selection and salience:

To frame is to select some aspects of a perceived reality and make them more salient in a communicating text, in such a way as to promote a particular problem definition, causal interpretation, moral evaluation, and/or treatment recommendation for the item described. (p. 52)

This promotion of particular points of view are often entrenched in agenda-setting practices in media, which I will be referring to as agendisation. In this section, I provide examples of the interviewed journalists' understandings of agenda-setting and the interviewed teachers' perceptions of media agendas are discussed as a means of understanding the effects of these practices.

Cohen (1963), over five decades ago, alluded to media practice of setting agendas in his statement: 'The press is significantly more than a purveyor of information and opinion'; he added 'It may not be successful much of the time in telling people what to think, but it is stunningly successful in telling its readers what to think about' ( $p$. 13). The practice of agenda-setting is a characteristic of institutionalism that seeks to foreground the problems and issues in strategic ways so as to amplify particular ideas and solicit support for preferred alternatives or approaches (Beland, 2009; Campbell, 2004). Agendisation is often overtly manifested within media organisations. For example, John Hartigan (2010), the former chairman and chief executive of News Corp Australia stated, 'My contention is this - we have the opportunity to move from setting the agenda each morning, to actually owning the agenda. All day. Every day' (n.p). This suggests that media organisations should be prepared to not only create, but also determine or dictate the news agendas of the day. Such ideology within media institutions is dangerous - first, because it is driven by what can be referred to as practices of 'accountabilisation', and second, it can be enounced in notions of exerting 'influence' over the public.

The role of media organisations is often assumed to be pivotal in ensuring public accountability by protecting public interests and raising public awareness. Fleur, a journalist I interviewed, stated:

I think our primary role is as the community's watch dog. Whether it's governments or social structures; holding them up to scrutiny. By scrutiny, I do not mean that we necessarily cast a judgment on them but we highlight or unveil or expose things for the community to judge; whether that is holding government to account or teachers and doctors to account ... We are the force of the day!

Here, she uses three key phrases: 'watch dog', 'scrutiny', and 'the force of the day'. The first two phrases aspire to the more democratic notions of the free press (Finkelstein \& Ricketson, 2012) acting as society's guardian and holding power to account; while the latter is about influence. These are common understandings by media practitioners of the role of media (see Baroutsis, 2016). For example, a recent review of media in Australia, the Finkelstein Inquiry, ${ }^{1}$ identified a role of media as being society's guardians (Finkelstein \& Ricketson, 2012). The question here is about the practices of accountabilisation within media organisations. Generally, the industry is self-regulating and there is a tendency to externalise the practice of demanding accountability and transparency of those they report on; these practices are not always 
adopted within their own organisation, thus resulting in the questioning of the effectiveness of industry self-regulation. For example, amongst other recommendations, the Finkelstein Inquiry proposed that a regulatory body be established to 'make the news media properly accountable' (Finkelstein \& Ricketson, 2012, p. 9). This gained unfavourable reception with many media practitioners, such as the then chief executive of News Corp Australia, Kim Williams, who stated, 'Greater government regulation and control of the media is at odds with the principles of freedom of expression' (Williams, 2012, n.p.); this was also described as 'preposterous' (Davidson, 2012, n.p.).

The second element of Fleur's statement above is that media are the 'force of the day'. This has connotations of media exerting influence. It could be said that this perceived role of newspaper text is to influence change. This makes newspapers 'performative texts' (Ball, 2000) in that they are potentially able to actively construct and transform social realities. Similarly, news institutions assume their role is to speak on behalf of society. Matheson (2005) suggests, 'media professionals in general are able to write or speak in authoritative ways about the world, making claims to know what other people feel or what is really happening which few others in society could get away with' (p. 2). Additionally, when this is presented in a 'factual' manner it legitimates and reinforces credibility in what is being said and who is saying it generating an 'oracle effect' (Bourdieu, 1991). By positioning themselves as speaking on behalf of society or 'the masses', as Bourdieu suggests, it is likely that media voices become enhanced within the scope of public perception, making the practice of agendisation dangerous and complex.

Agendisation and accountabilisation are practices that are often associated with newspapers, in particular campaigning newspapers, which operate through media logics. The Australian is one such campaigning newspaper, and critiques of teachers and teaching is an agenda item that can be seen within the pages of this newspaper. Similar to Birks (2010), the two journalists I spoke to supported the practice of agendisation through campaigning, particularly as there is the perception that this fulfils a democratic purpose. Fleur, a journalist, indicated: 'There's a long, proud tradition in print media of campaigning and campaigning newspapers'. However, as Mazzoleni and Schulz (1999) suggest, newspapers function within a 'mediatised democracy' that 'can distort the proper functioning of democracy' (p. 259). As such, Burgess (2010) identifies a campaigning newspaper as one that undertakes the 'conscious and systematic promotion of particular causes and issues' (p. 60) thereby defining one particular version of 'reality'. Birks (2010) adds that such newspapers, in contrast to practices of investigative journalism, make 'claims to represent some form of public or "public opinion"” (p. 208). Campbell (2004) indicates ideas can be understood as public sentiments that identify what is 'desirable' or 'expected'. However, Bourdieu (2011) quite bluntly states that while 'journalists point to the public's expectations but in fact they are projecting onto the public their own inclinations and their own views' (p. 3); there is a tendency to 'overtly express a substantive, value-oriented bias, with the purpose of influencing policy decisions' (Birks, 2010, p. 209). As a consequence of the practice of agendisation, issues such as teachers' work become mediatised and lose autonomy, thereby being shaped through interactions with the mass media (Mazzoleni \& Schulz, 1999).

Both the journalists and the teachers in this project were acutely aware of the media practice of agendisation. Ron, a journalist explained: 'Yes ... We push an agenda ... It is a bad thing in a case where a particular newspaper proprietor wants a particular political party elected at the next election.' Whilst not specifically referring to 
teachers, Ron's example can be seen as an understanding of the imperative to hold teachers to account. However, teachers who were interviewed tended to disagree with this perspective, and negatively perceived the media agendas about their work. For example, Fred, a secondary school teacher and union officer suggested it was a 'deliberate campaign', stating 'I think the campaign run by The Australian newspaper ... was a total beat-up' that was 'designed to really attack [teachers and schools]'. In contrast, Fleur, the journalist suggested: '. .. if people don't agree with the campaign they are more critical or see that as pushing a particular point of view. But I think campaigning on an issue is saying that this issue is important and this issue needs to be addressed'. Perhaps, like Burgess (2010), who identified the element of media 'self-righteousness' as a characteristic of media agendas and campaigns, the teachers perceived media reportage to be somewhat calculated and conceited.

In trying to understand the media logics surrounding agendisation driven by accountabilisation, the editorial and journalistic motives for the selection of particular news reports can be explored. When considering the motivation for newspaper campaigns, Birks (2010) suggests that the goal is to influence policy decisions. Elsewhere, Roberts and McCombs (1994) add 'the number of potential sources shaping the media's agenda is large, ranging from external sources in government and the private sector to the idiosyncrasies of individual journalists' (p. 247). As well as these motivations of agendisation, decisions about framing can also be derived from the notion of 'responding to the public', or public 'interest' and public 'good'. However, in so doing, Mayer (1994) suggests 'they construct the very public issues they write about' (p. 37). For example, Ron, a journalist, indicated: 'The community will set the agenda on certain stories'. Mayer (1994) suggests 'newspapers are accountable to or responsive to their readership only to the extent that their owners and editors decide that they should be' (p. 27) and 'social responsibility' is only heeded if it aligns with 'good business' (p. 28), which is seen as a greater motivator. Consequently, business decisions can also potentially frame news issues in education. Agendisation is a media mentality that is aligned with practices of accountabilisation. Both are institutional practices of media logics. Derived from motivations of social responsibility and encumbered by financial gains, the news is framed by media organisations and constructs particular realities of teachers' work.

The next three sections identify a number of journalistic practices, spawned from the above institutional practices, that are also governed by media logics: factualisation, emphasisation, and sensationalisation.

\section{Factualisation}

News texts focus on portraying 'factual' accounts of the issues as part of a 'fact construction discourse' (Potter, 2003). Media organisations are often focused on portraying themselves as 'impartial', 'neutral', 'balanced', and 'objective' as part of their professional ethic (Burton, 2005). Interestingly, given this and as stated earlier, first, their professionalism is drawn from self-regulation rather than external systems, therefore any statements of objectivity are drawn from within this closed environment. Second, media understandings of impartiality, neutrality and balance are framed within the context of agendisation that seek to frame particular news in particular ways. However, these ideals are coupled with the imperative of being seen as a trusted and credible source of information by their audiences. One key way of projecting this is through practices of 'factualisation'. 
It is often stated (Hacking, 1999; Latour \& Woolgar, 1986) that words such as 'facts' are paradoxical; with Barthes (1977) adding that 'every fact possesses several meanings (a plurality of 'interpretations')' (p. 209). When observing the practices of journalism governed by media logics, facts tend to be identified through statements that are taken to be fixed and impermeable 'truths' about 'reality'. At times, demonstrating understandings of a 'commonsense reality' (Hacking, 1999) and absolute truth; instead of a multiplicity and plurality of realities and truths. In critiquing these media logics, I draw on Hacking who suggests, that 'statements state facts' but are not facts in themselves. Additionally, Latour and Woolgar (1986) note that the notion of 'reality' is not an appropriate means of identifying something as a fact.

Despite this, as Tuchman (1980) found, within the professional practice of media practitioners and expectations of the public, there is a demand that the news is reported through a 'web of facticity'. This 'facticity connote[s] professional neutrality and objectivity' (p. 160) of the journalists and the newspaper. Fleur, the journalist, genuinely stated:

There is, and I know this is scoffed at, a code of ethics that guides our practice. There are certain beliefs that we hold firm to, such as presenting both sides of the story, fair and accurate reporting, trying to get it right as much as we can, keeping opinion and comment very clearly differentiated from reporting of news and facts ... I'm not the expert; I'm the medium ... My own views don't come into the way I approach the story. We try, as much as we can to be neutral.

Tuchman (1980) indicates that fact-finding entails a demonstration of impartiality by the journalist which includes ensuring accuracy and 'removing oneself from a story' (p. 83). This neutrality works to create a distance between the journalist and what is being said. Potter (2004) refers to this as a 'construction of impersonality' where journalists are constructed as 'animators' who are merely reporting the claims and views of other people.

Similarly, this perception of the importance of 'objective' media was also identified by some teachers in this study. For example, Neville, a secondary school teacher and curriculum association officer was critical of media practices that strayed from facts:

... there is a blurring of fact and opinion. Now newspapers clearly have a place to report facts and to also publish opinions but often there is a blurring of the one and the other ... if it [opinion] is repeated loudly enough and often enough, is treated as though it were fact ... They [newspapers] don't provide any evidence of that. It's presented as a self-evident claim.

Here, the suggestion is that 'objective fact', supported by 'evidence', is juxtaposed with personal opinion, that is, a distinction is made between 'factual and interpretive materials' (Tuchman, 1980, pp. 98-99).

While investigative stories are often those governed by practices presented as adhering to the pursuit of factualisation, the editorial and 'op-ed' pages provide an opportunity for the newspaper to provide commentary and opinion. Within the scope of this freedom of expression, the editorial and op-ed pages provide a platform to express the editorial line, that is, the opinion of the editors, publishers, and owners of the newspapers. Fleur expressed this distinction, commenting:

In the editorials and the opinion pages, the paper might push a separate line ... The opinion and the commentary take a different line and that's the newspaper's prerogative ... So, I think it is important to remember there is a distinction between a news report and what an opinion writer says or what the editorial says. 
When referring to the editorial line, she also added that this can determine the selection of news items that are approved for print. Fleur stated:

You could argue that perhaps the views presented in the opinion pages are more one-sided than another, and I wouldn't think you were wrong with that. Having said that, I think that it can cast the selection of news stories. So, if I am writing a story that is contrary to a particular editorial line, I might find it harder to get a bigger run, sometimes, not always, but you could mount an argument that it colours placement and selection of stories.

Here, the link to agendisation is clear. While the focus of media rhetoric tends toward factualisation, the practices translate in more pragmatic terms where agenda-setting is controlled through editorial practices that see journalists vying for their stories to be selected for print by the editorial staff. This being attained when stories are aligned to the editorial views. As Bourdieu (2011) suggests, 'competition homogenizes when it occurs between journalists' (p. 23).

The next two practices of media logics, emphasisation and sensationalisation, will provide textual examples of these practices, which are intertwined with the previously outlined mentalities of agendisation, accountabilisation, and factualisation.

\section{Emphasisation}

As a campaigning newspaper, The Australian utilises practices of agendisation with one construction of teachers being related to 'quality'. For example, in this study, $51 \%$ of the news reports cited issues of teacher quality within their text. This practice of agendisation also aligns with the practice of emphasisation, used to reinforce the dominant media understandings of the issues. While it is not within the scope of this paper to outline and problematise the notion of teacher quality, I outline media understandings of this construction of teachers and the practice of emphasisation. The following excerpts from news reports by a journalist and opinion writers provide examples of this emphasis on teacher quality. First, one article suggested, 'It is more important for a student to have an effective teacher than to be in a class with a few less students' (Ferrari, 2010, p. 3, emphasis added). Another, from the same reporter indicated, 'The biggest difference a school can make to a student's education, and therefore their life, is the quality of the teacher' (Ferrari, 2011, p. 3, emphasis added). Both these news reports focus on the quality of the teacher. Second, op-ed commentary in the newspaper suggested: 'Anyone who knows much about education and teaching understands this simple fact: quality educational outcomes are directly related to quality teaching' (Bantick, 2010, p. 14, emphasis added). Another commentary piece indicated: 'High-performing systems internationally recognise that the key to increased student performance is high-quality teaching' (Masters, 2010, p. 14). In contrast to the first examples, these op-ed stories identify quality teaching as being of great importance. However, such reports that focus on quality teaching were fewer in contrast to those referring to quality teachers.

This raises the question as to why the notion of quality teachers, rather than quality teaching, was emphasised in The Australian newspaper. Additionally, it is interesting to note that even though many newspaper texts referred to teacher quality, they were in fact discussing teaching quality. While both the terms are value-laden, teacher quality is usually associated with the knowledge, skills, competencies, dispositions, and personal characteristic of the individual; and is only one component of teaching quality (Darling-Hammond, 2009). Additionally, as Darling-Hammond suggests, this 
does not recognise that teaching is strongly influenced by contextual factors such as having the necessary supplies and equipment or reasonable class sizes (p. 3). This understanding of the significance of contextual factors was rarely evident in newspaper reports and media discourses. Additionally, even when the level of government spending on education was addressed in the newspaper, the emphasis was still on teacher quality, suggesting that the increased taxpayer dollars being spent on education did not translate into improved outcomes due to the poor quality of teachers (see, for example, Trounson, 2009, p. 3). Reportage often cited problems with teachers' capability to teach, including their credentials and training (Ferrari, 2009a; Hohenboken, 2009; The Australian, 2009); their ineffectiveness as teachers, especially in relation to poor student outcomes (Bantick, 2010; Ferrari, 2010); and at times, even teachers' intelligence (Albrechtsen, 2009). The 'problem' of teacher quality was debated in the press as part of the practice of agendisation. This was followed by a scramble to provide media commentary on how to improve teacher quality. As Bourdieu (2011) suggests, such practices create 'a reality effect' in that 'they show things and make people believe in what they show. This power to show is also a power to mobilize. It can give a life to ideas or images, but also to groups' ( $p$. 21). Therefore, such coverage constructs a grim public picture of teachers.

\section{Sensationalisation}

Another practice of media logics is sensationalisation, designed to 'gain [the] attention' of the audience and draw them in, as well as 'ferment opinion' about an agenda or campaign (Örnebring \& Jönsson, 2004, p. 291). Sensationalisation may, at times, be at odds with practices of factualisation, even though, as I will show, the two practices still operate together within media logics. Rita, a primary school teacher and a former journalist indicated:

If you look at a story and what they run with, it can sometimes be the smallest part, the least important part, but because it is sensational, it is going to give them the biggest 'bang' ...

Sometimes the language that is used in a way that portrays the sensational aspect. It ends up doing teachers and education a disservice.

As Rita indicated, often, sensationalist stories engage with positioning or 'spin' designed to purposefully present an issue in a favourable way to as to mobilise support (Gewirtz, Dickson, \& Power, 2004). Take for example, a news report titled, 'Three in five high schools rely on "untrained" teachers' (Hohenboken, 2009), published in The Australian, that highlights a situation where teachers teach outside of their field of expertise (see Du Plessis, Carroll, \& Gillies, 2015). The article is drawn from the findings in a teachers' union report by the Australian Education Union (AEU) titled, 'The State of our schools', detailing the findings of a survey of 1473 public school principals. The newspaper article states:

\footnotetext{
Almost 60 per cent of Australia's government-run schools experience problems sourcing teachers last year and about 30 per cent have teachers running classes outside their areas of expertise. Among secondary schools, the percentage with classes taught by teachers not trained in that subject is a staggering 58 per cent. (Hohenboken, 2009, p. 7)
}

The provocation in the text is drawn from the bold headlines, statistics, and the choice of words. The headline claimed teachers are 'untrained' to teach the various subjects they are assigned. While I note that the word 'untrained' was placed in inverted 
commas, the choice of the word interpreted the AEU data in a way that was not identified in the original documentation of the research findings. When the body of the news report is analysed, it aligned more closely with the AEU findings, stating that teachers were not in fact 'untrained', but rather teaching 'outside their areas of expertise' in subjects they are not qualified to teach. These differences between the suggestion in the headline and the body of the news report is perhaps due to different people in media organisations writing each component. Ron, a journalist in my study explained:

Some papers encourage their journalists to write a suggested headline, others don't. It is the sub-editor who is preparing the article for publication who actually writes the headline. Even the headline that that journalist writes can get changed by the editor.

I posit that the changes to the headlines relate to practices of sensationalisation. Additionally, simple statistics were used, augmenting these with adjectives such as 'staggering'. That is, the statement could read: 'the percentage with classes taught by teachers not trained in that subject is a staggering 58 per cent'.

Another aspect of sensationalisation, aligned with practices of factualisation, is the use of 'independent' reports produced by non-government business agencies external to education systems. Lubienski, Scott, and DeBary (2011) suggest that such 'intermediary organizations' play 'decisive roles in gathering, interpreting, and packaging particular research for policymakers' (n.p.). As it seems, this role of packaged research also extends to media in that such reports are almost always used by the press in preference to scholarly research produced by university researchers. The Australian often used reports from McKinsey \& Company (http://www.mckinsey.com), a global management consulting firm with offices across Europe; the Grattan Institute (http://grattan.edu.au), and the Centre for Independent Studies (https://www.cis.org.au/), both right-wing independent think tanks in Australia; and the Australian Council for Education Research (ACER) (https://www.acer.edu.au/), an independent non-government organisation. Coffield (2012) is highly critical of such reports suggesting they are often methodologically flawed, selective, superficial and implausible regarding their central arguments, have a thin evidential base for their claims, and an impoverished view of teachers and teaching (also see Lingard, 2016). Media practices of sensationalisation operate through the use of such packaged research.

\section{Conclusions}

The media mentalities that govern the institutional practices of agendisation and accountabilisation, draw on journalistic practices such as factualisation, emphasisation and sensationalisation to enhance the impact and development of perceived issues related to teachers' work. Practices of emphasisation draw on practices of factualisation to develop greater credibility for the newspaper as an authoritative voice on the topic at hand, thereby ensuring the longevity of the issue. At times, sensationalisation and factualisation are incongruent but often practised together to push accountabilisation. Through a process of what Bourdieu (2011) refers to as 'permanent amnesia', the outlined media mentalities or practices that operate on media logics, narrow the scope and range of stories that media report on.

These media mentalities often tend toward simple and short-sighted understandings of complex issues, causing reputational damage to teachers and schools, and eroding public trust. Given the large volume of articles in The Australian reporting on 
teachers' work, this can potentially steer public opinion towards notions of large-scale crisis in teaching in Australian schools. As such, generating a 'manufactured crisis' (Berliner \& Biddle, 1995) through this disproportionate focus on the negative aspects of teaching. As educators, we should be political actors who are media-aware, and as a society we should avoid normalising reductionist discourses about teachers and their work.

\section{Note}

${ }^{1}$ The Report of the Independent Inquiry into Media and Media Regulation was commissioned in 2011 by the Australian Government to review aspects of media, media regulation, and accountability.

\section{References}

Albrechtsen, J. (2009, 7 October). Sound method key to literacy. The Australian, p. 12.

Altheide, D. L. (2013). Media logic, social control, and fear. Communication Theory, 23(3), 223-238.

Altheide, D. L., \& Snow, R. P. (1979). Media logic (Vol. 89). Beverly Hills: SAGE.

Asp, K. (2014). News media logic in a new institutional perspective. Journalism Studies, 15(3), 256270.

Ball, S. J. (2000). Performativities and fabrications in the education economy: Towards the performative society? Australian Educational Researcher, 27(2), 1-23.

Bantick, C. (2010, 1 February). Poor teachers, poor results. The Australian, p. 14.

Baroutsis, A. (2016). Media accounts of school performance: Reinforcing dominant practices of accountability. Journal of Education Policy, 31(5), 567-582.

Barthes, R. (1977). Image, music, text (S. Heath, Trans.). London: Fontana Press.

Beland, D. (2009). Ideas, institutions, and policy change. Journal of European Public Policy, 16(5), 701-718.

Berliner, D. C., \& Biddle, B. J. (1995). The manufactured crisis: Myths, frauds, and the attack on America's public schools. New York: Longman.

Birks, J. (2010). The democratic role of campaign journalism. Journalism Practice, 4(2), 208-223.

Bourdieu, P. (1991). Language and symbolic power. Cambridge, UK: Polity Press in association with Basil Blackwell.

Bourdieu, P. (2011). On television. Cambridge, UK: Polity.

Burgess, A. (2010). Media risk campaigning in the UK: From mobile phones to 'Baby P'. Journal of Risk Research, 13(1), 59-72.

Burton, G. (2005). Media and polular culture. London: Hodder \& Stoughton.

Campbell, J. L. (2004). Institutional change and globalization. Princeton: Princeton University Press.

Coffield, F. (2012). Why the McKinsey reports will not improve school systems. Journal of Education Policy, 27(1), 131-149.

Cohen, B. (1963). The press and foreign policy. Princeton, N.J: Princeton University Press.

Cook, T. E. (2005). Governing with the news: The news media as a political institution. Chicago: University of Chicago Press.

Couldry, N. (2003). Media rituals: A critical approach. London: Routledge. 
Cunningham, S., \& Turner, G. (Eds.). (2010). The media and communications in Australia (3 ed.). Crows Nest, AU: Allen \& Unwin.

Darling-Hammond, L. (2009). Recognising and enhancing teacher effectiveness. The International Journal of Educational and Psychological Assessment, 3(Dec), 1-24.

Davidson, D. (2012, 13 July). News to challenge media regulation. The Australian. Retrieved from http://www.theaustralian.com.au/media/news-to-fight-media-regulation/story-e6frg9961226425441232

Davis, M. (1997). Gangland: Cultural elites and the new generationalsim. St Leonards, AU: Allen \& Unwin.

Dean, M. (2010). Governmentality: Power and rule in modern society (2 ed.). London: SAGE.

Du Plessis, A., Carroll, A., \& Gillies, R. M. (2015). Understanding the lived experiences of novice outof-field teachers in relation to school leadership practices. Asia-Pacific Journal of Teacher Education, 43(1), 4-21.

Entman, R. M. (1993). Framing: Toward clarification of a fractured paradigm. Journal of Communication, 43(4), 51-58.

Entman, R. M. (2004). Projections of power: Framing news, public opinion, and US foreign policy. Chicago, IL: University of Chicago Press.

Ferrari, J. (2009, 17 March). Curriculum 'beyond teachers' skills'. The Australian, p. 3.

Ferrari, J. (2010, 15 November). Teacher, not class size, key to results. The Australian, p. 3.

Ferrari, J. (2011, 10 February). What happens next is critical to making it work. The Australian, p. 3. Finkelstein, R., \& Ricketson, M. (2012). Report of the independent inquiry into the media and media regulation. Canberra, AU: Department of Broadband, Communications and the Digital Economy.

Foucault, M. (1972). The archaeology of knowledge and the discourse on language (A. M. SheridanSmith, Trans.). New York: Vintage Books.

Foucault, M. (1981). The order of discourse. In R. Young (Ed.), Untying the text: A post-structuralist reader (pp. 48-78). Boston: Routledge and Kegan Paul.

Foucault, M. (1991a). Governmentality. In G. Burchell, C. Gordon, \& P. Miller (Eds.), The Foucault effect: Studies in governmentality: With two lectures by and an interview with Michel Foucault (pp. 87-104). Chicago: University of Chicago Press.

Foucault, M. (1991b). Politics and the study of discourse. In G. Burchell, C. Gordon, \& P. Miller (Eds.), The Foucault effect: Studies in governmentality: With two lectures by and an interview with Michel Foucault (pp. 53-72). Chicago: University of Chicago Press.

Foucault, M. (1991c). Questions of method. In G. Burchell, C. Gordon, \& P. Miller (Eds.), The Foucault effect: Studies in governmentality: With two lectures by and an interview with Michel Foucault (pp. 73-86). Chicago: University of Chicago Press.

Gewirtz, S., Dickson, M., \& Power, S. (2004). Unravelling a 'spun' policy: A case study of the constitutive role of 'spin' in the education policy process. Journal of Education Policy, 19(3), 321342.

Hacking, I. (1999). The social construction of what? Cambridge, MA: Harvard University Press.

Hartigan, J. (2010). Opening address by the chairman and chief executive of News Limited. Paper presented at the Pacific Area Newspapers Publishers' Association (PANPA) Annual Future Forum Conference, Sydney, Australia.

Hepp, A. (2012). Mediatization and the 'molding force' of the media. Communications: The European Journal of Communication Research, 37(1), 1-28.

Hjarvard, S. (2008). The mediatization of society: A theory of the media as agents of social and cultural change. Nordicom Review, 29(2), 105-134. 
Hjarvard, S. (2009). Soft individualism: Media and the changing social character. In K. Lundby (Ed.), Mediatization: Concept, changes, consequences (pp. 159-177). New York: Peter Lang.

Hohenboken, A. (2009, 27 October). Three in five high schools rely on 'untrained' teachers. The Australian, p. 7.

Lacey, C., \& Longman, D. (1997). The press as public educator: Cultures of understanding, cultures of ignorance. Bedfordshire, LU: University of Luton Press.

Landerer, N. (2013). Rethinking the logics: A conceptual framework for the mediatization of politics. Communication Theory, 23(3), 239-258.

Latour, B., \& Woolgar, S. (1986). Laboratory life: The construction of scientific facts. Princeton, NJ: Princeton University Press.

Lingard, B. (2016). Think tanks, 'policy experts' and 'ideas for' education policy making in Australia. Australian Educational Researcher, 43(1), 15-33.

Lubienski, C., Scott, J., \& DeBary, E. (2011). The rise of intermediary organizations in knowledge production, advocacy, and educational policy. Teachers College Record, Retrieved from http: Ilwww.tcrecord.org ID Number: 16487

McKnight, D. (2010). Rupert Murdoch's News Corporation: A media institution with a mission. Historical Journal of Film, Radio and Television, 30(3), 303-316.

Masters, G. (2010, 8 December). Reading between lines, barely a pass for teachers. The Australian, p. 14.

Matheson, D. (2005). Media discourses: Analysing media texts. Maidenhead, UK: Open University Press.

Matthes, J. (2009). What's in a frame? A content analysis of media framing studies in the world's leading communication journals, 1990-2005. Journalism \& Mass Communication Quarterly, $86(2), 349-367$.

Mayer, H. (1994). Mayer on the media: Issues and argument, (R. Tiffen Ed.). North Ryde, AU: Allen \& Unwin.

Mazzoleni, G., \& Schulz, W. (1999). 'Mediatization' of politics: A challenge for democracy? Political Communication, 16(3), 247-261.

Meyer, T. (2002). Media democracy: How the media colonize politics. Cambridge, UK: Polity.

Mills, M., \& Keddie, A. (2010). Cultural reductionism and the media: Polarising discourses around schools, violence and masculinity in an age of terror. Oxford Review of Education, 36(4), 427-444.

Örnebring, H., \& Jönsson, A. M. (2004). Tabloid journalism and the public sphere: A historical perspective on tabloid journalism. Journalism Studies, 5(3), 283-295.

Paletz, D. L., \& Entman, R. M. (1981). Media power politics. New York: The Free Press.

Papandrea, F., \& Tiffen, R. (2011). Media concentration in Australia. Retrieved from http://internationalmedia.pbworks.com/w/file/46422518/Draft\%20Australian\%20Chapter\%20\%28 June2011_Rev\%29.docx

Patton, M. Q. (2002). Qualitative research and evaluation methods (3rd ed.). Thousand Oaks, CA: SAGE.

Potter, J. (2003). Representing reality: Discourse, rhetoric and social construction. London: SAGE.

Potter, J. (2004). Discourse analysis as a way of analysing naturally occurring talk. In D. Silverman (Ed.), Qualitative research: Theory, method and practice (2nd ed.), (pp. 200-221). London: SAGE.

Rawolle, S. (2010). Understanding the mediatisation of educational policy as practice. Critical Studies in Education, 51(1), 21-39. 
Rawolle, S., \& Lingard, B. (2010). The mediatization of the knowledge based economy: An Australian field based account. Communications: The European Journal of Communication Research, 35(3), 269-286.

Ricoeur, P. (2009). Memory, history, forgetting (K. Blamey \& D. Pellauer, Trans.). Chicago: University of Chicago Press.

Roberts, M., \& McCombs, M. (1994). Agenda setting and political advertising: Origins of the news agenda. Political Communication, 11(3), 249-262.

Shoemaker, P. J., Vos, T. P., \& Reese, S. D. (2009). Journalists as gatekeepers. In T. Hanitzsch \& K. Wahl-Jorgensen (Eds.), The handbook of journalism studies (pp. 73-87). New York: Routledge.

Strömbäck, J., \& Dimitrova, D. V. (2011). Mediatization and media interventionism: A comparative analysis of Sweden and the United States. International Journal of Press/Politics, 16(1), 30-49.

Strömbäck, J., \& Esser, F. (2014). Mediatization of politics: Transforming democracies and reshaping politics. In K. Lundby (Ed.), Mediatization of communication (Vol. 21, pp. 375-403). Berlin: De Gruyter.

The Australian. (2009, 4 March). Nation lacking maths teachers. The Australian, p. 1.

Thomas, S. (2002). Contesting education policy in the public sphere: Media debates over policies for the Queensland school curriculum. Journal of Education Policy, 17(2), 187-198.

Thomas, S. (2006). Education policy in the media: Public discourses on education. Teneriffe, AU: Post Pressed.

Tiffen, R. (2010). The press. In S. Cunningham, \& G. Turner (Eds.), The media and communications in Australia (3rd ed.), (pp. 81-95). Crows Nest, AU: Allen \& Unwin.

Trounson, A. (2009, 15 January). School output the key measure. The Australian, p. 3.

Tuchman, G. (1980). Making news: A study in the construction of reality. New York: Free Press.

Williams, K. (2012). Speech: You can't hold back the tide. Retrieved from http://www.sapressclub.com.au/ 